

\section{Daftar Isi (Table of Content) Journal of Government
Civil Society}

\begin{tabular}{|c|c|}
\hline \multirow{3}{*}{$1-30$} & $\begin{array}{l}\text { The Application of Social Movement as a Form of Digital Advocacy: Case of } \\
\text { \#TolakRUUPermusikan }\end{array}$ \\
\hline & Muhammad Ananda Alifiarry', Bevaola Kusumasari ${ }^{1}$ \\
\hline & $\begin{array}{l}\left({ }^{1} \text { Department of Public Policy and Management, Faculty of Social and Political Sciences, }\right. \\
\text { Universitas Gadjah Mada, Indonesia) }\end{array}$ \\
\hline \multirow{3}{*}{$31-50$} & $\begin{array}{l}\text { Urban Resilience Strategy in the Climate Change Governance in Makassar } \\
\text { City, Indonesia }\end{array}$ \\
\hline & $\begin{array}{l}\text { Ihyani Malik }{ }^{1} \text {, Andi Luhur Prianto }{ }^{2} \text {, Abdillah Abdillah², Zaldi Rusnaedy }{ }^{3} \text {, } \\
\text { Andi Annisa Amalia }{ }^{4}\end{array}$ \\
\hline & $\begin{array}{l}\text { ('Department of Public Administration, Universitas Muhammadiyah Makassar, Indonesia) } \\
\text { ('Department of Government Studies, Universitas Muhammadiyah Makassar, Indonesia) } \\
\left({ }^{3} \text { Department of Government Studies, Universitas Pancasakti Makassar, Indonesia) }\right. \\
\text { (4 Department of Architecture, Faculty of Engineering, Universitas Muhammadiyah } \\
\text { Makassar, Indonesia) }\end{array}$ \\
\hline \multirow{3}{*}{$51-63$} & $\begin{array}{l}\text { Collaboration Governance in The Development of Natural Based Tourism } \\
\text { Destinations }\end{array}$ \\
\hline & Muchamad Zaenuri11, Yusrim Musa ${ }^{1}$, Muhammad Iqbal ${ }^{2}$ \\
\hline & $\begin{array}{l}\text { ('Department of Government Affairs and Administration Universitas Muhammadiyah } \\
\text { Yogyakarta, Indonesia) } \\
\text { ('Department of Political Science National Cheng Kung University, Taiwan, Province of } \\
\text { China) }\end{array}$ \\
\hline \multirow{3}{*}{$65-80$} & $\begin{array}{l}\text { Analysis of Mind Patterns and Work Culture in Government of West } \\
\text { Pasaman District }\end{array}$ \\
\hline & $\begin{array}{l}\text { Sri Andri Yani }{ }^{1} \text {, Etika Khairina }{ }^{1} \text {, Suswanta }{ }^{1} \text {, Mochammad Iqbal } \\
\text { Fadhlurrohman }{ }^{1}\end{array}$ \\
\hline & ( ${ }^{1}$ Governmental Studies, Universitas Muhammadiyah Yogyakarta, Indonesia) \\
\hline \multirow{2}{*}{$81-92$} & $\begin{array}{l}\text { The Influence of Social Media (Instagram) of Bantul's General Election } \\
\text { Commissions on Voters Participation in the } 2019 \text { Elections }\end{array}$ \\
\hline & $\begin{array}{l}\text { Agus Priyanto' }{ }^{1} \text { Eko Priyo Purnomo }{ }^{1,2} \text {, Mochammad Iqbal } \\
\text { Fadhlurrohman', Herry Fahamsyah'1, Etika Khairina1 }^{1}\end{array}$ \\
\hline
\end{tabular}


( ${ }^{1}$ Departement of Government Affairs and Administration, Universitas Muhammadiyah Yogyakarta, Indonesia)

(2 Jusuf Kalla School of Government, Universitas Muhammadiyah Yogyakarta, Indonesia)

Model Implementation Trap of Policy New Student Acceptance Zoning System in Makassar City

93 - 108 Nuryanti Mustari' ${ }^{1}$, Rudi Hardi ${ }^{1}$, Amir Muhiddin ${ }^{1}$

('Department of Government Studies, Faculty of Social and Political Sciences, Universitas Muhammadiyah Makassar, Indonesia)

Collaborative Urban Governance Model in Environmental Management of Industrial Area

\section{Tri Sulistyaningsih', Saiman', Nofianda Fatimah Azzahra' ${ }^{1}$, Nanda}

$109-128$ Adityawan'2, Mohammad Jafar Loilatu ${ }^{3}$

$\left({ }^{1}\right.$ Department of Government Studies, Universitas Muhammadiyah Malang Indonesia) ( ${ }^{2}$ Civil Engineering, Sepuluh Nopember Institute of Technology, Surabaya, Indonesia) $\left({ }^{3}\right.$ Government Affairs and Administration, Universitas Muhammadiyah Yogyakarta, Indonesia)

Towards an Integration of Immigration and Customs Agency in Indonesia: A Step-by-Step Process

\section{9 - $146 \quad$ Ridwan Arifin' ${ }^{1}$, Intan Nurkumalawati ${ }^{1}$}

(1 Diploma Program of Immigration Administration, Polytechnic of Immigration, Indonesia) 


\title{
Towards an Integration of Immigration and Customs Agency in Indonesia: A Step-by-Step Process
}

\author{
Ridwan Arifin $^{1^{*}}$, Intan Nurkumalawati ${ }^{1}$ \\ ${ }^{1}$ Diploma Program of Immigration Administration, Polytechnic of Immigration, Indonesia \\ *Email Correspondence: ridwan.arifin@poltekim.ac.id
}

\begin{abstract}
Some challenges appear in this issue that the Indonesian border agencies indicate weaknesses in coordination, fragmented policy instruments, and disputes in implementing laws. There has little evidence in the previous study about the integration of border agencies in Indonesia and perspectives on the establishment of immigration and customs agencies. The questions may arise how important is the integrated border agencies is in the reform agenda in public sectors and bureaucracy from the perspectives of border officers. This study is to figure out the perspectives of border officers on the integration of two border authorities in Indonesia and what the ideal integration should be. This paper provides solutions for some issues of border protection in Indonesia with survey research and a step-by-step process of integration. This paper finds most immigration and customs officers at border controls exposed the importance of an integration initiative between the Directorate General of Immigration (DGI) and Directorate General of Customs and Excise (DGCE) in Indonesia through the Integrated Border Management (IBM) strategy. Therefore, initiating the integration of institutions between the Directorate General of Immigration and Directorate General of Customs and Excise, such as ICA Singapore or ABF Australia is more ideal border agencies rather than a joint-task force.
\end{abstract}

Keywords: customs inspection, immigration control, border management, whole-of-government

\begin{abstract}
ABSTRAK
Permasalahan di instansi pemerintah yang menangani perbatasan di Indonesia masih terjadi seperti adanya kelemahan dalam koordinasi, terdapat instrumen kebijakan yang terpisah-pisah, dan terjadinya tumpang tindih dalam penegakan hukum. Penelitian sebelumnya tentang inisiasi integrasi instansi di perbatasan Indonesia masih sangat minim terutama penggabungan dua otoritas perbatasan seperti imigrasi dan bea cukai. Pertanyannya adalah seberapa penting penggabungan dua otoritas perbatasan tersebut dalam rangka agenda reformasi birokrasi di sektor publik dari perspektif petugas perbatasan. Studi ini menggunakan penelitian survei dengan melihat perspektif dari petugas perbatasan terhadap integrasi dua otoritas perbatasan di Indonesia dan bagaimana seharusnya bentuk ideal penggabungan tersebut. Hasil penelitian menunjukkan bahwa sebagian besar petugas imigrasi dan kepabeanan menyatakan sangat setuju dengan inisiasi penggabungan Direktorat Jenderal Imigrasi dan Direktorat Jenderal Bea dan Cukai dengan menerapkan strategi manajemen perbatasan terintegrasi (IBM). Integrasi dua tersebut dalam bentuk badan baru seperti ICA Singapore atau ABF Australia ketimbang tim atau gugus tugas yang bersifat sementara.
\end{abstract}

Kata Kunci: pemeriksaan kepabeanan, pemeriksaan keimigrasian, manajemen perbatasan, pemerintahan terintegrasi

Citation : Arifin, R., \& Nurkumalawati, I. (2021). Towards an Integration of Immigration and Customs Agency in Indonesia: A Step-by-Step Process. Journal of Government and Civil Society, 5(1), 129-146. 


\section{INTRODUCTION}

Indonesia is the archipelago country with around 17,000 islands, and the coastline lies $54,720 \mathrm{~km}$ with the land border reaches 3,096 km lengths. It illustrates the Indonesian territory is located between two oceans and a very strategic position, and Indonesia's borders share with nine countries. The Indonesia maritime boundary agreement with Australia and Timor Leste shall be finalized in relation to the seabed, continental shelf, and exclusive economic zone (EEZ), also with the Indonesia-Malaysia maritime boundary disputes, Indonesia-Philippines sea border renegotiation, and the special economic zone between Indonesia and Singapore. Indonesian border control at points of entry and exit are officially appointed: 37 border controls at airports, 90 controls at seaports, 11 stations at the land border, and 44 traditional borders based on the Indonesian Law and Human Rights Ministerial Letter 2020.

This paper is to measure the importance level of integration of border agencies in Indonesia between the Directorate General of Immigration (DGI) and Directorate of Customs and Excise (DGCE). These two border agencies concern about border security and protection at points of entry as a fundamental aspect of national sovereignty and economic growth. However, they belong to a different part of departments where the DGI is part of the Ministry of Laws and Human Rights, and DGCE is under the Ministry of Finance. The first issue relates to some border agencies from different ministries where they work at points of entry and exit, such as international airports, seaports, border crossing stations, and other premises across Indonesia's border. According to the Indonesian Immigration Act No.6 of 2011, the Indonesian Immigration Agency or Directorate General of Immigration (DGI) under the Ministry of Law and Human Rights play significant roles in protecting borders and border integrity in relation to people's movement or migration and their documents. In addition to border security and protection in Indonesia, the Directorate General of Customs and Excise has responsibilities for customs protection and law enforcement, such as preventing illegal goods, illicit drugs, and other dangerous items based on the Indonesian Customs Act No.17 of 2006.

A further issue in Indonesia is now facing transnational organized crime through borders that threaten national sovereignty, likewise serious drug crime, people smuggling, human trafficking, illegal fishing, terrorism, cybercrime, maritime security, and piracy. It causes Indonesia as a transit country for irregular migrants who escape from their origin countries to destination countries like Australia and Malaysia. According to the UNCHR data in 2018, about 14,000 irregular migrants are entering the Indonesian territory by air, illegal boats, and land borders along with data of the National Statistics Bureau, which in 2018 mentions the number of travelers to Indonesia up to 15.8 million (BPS, 2018). During the 2018 operation, the Indonesian Customs Agency has exposed 196 cases and stopped 4,075 tons of narcotics smuggling. As such reasons, this study is to provide solutions for 
some issues of border protection in Indonesia with survey research. The integration of DGCE and DGI Indonesia is significantly important through the Integrated Border Management (IBM) strategy. There has little evidence in the previous study about the future integration of border agencies in Indonesia and perspectives on the establishment of immigration and customs agencies.

As discussed, some challenges appear in this issue that the Indonesian border agencies indicate weaknesses in coordination, fragmented policy instruments, and disputes in implementing laws. The question arises: how is the perspective of border officers towards the integration of DGCE and DGI Indonesia in the framework of IBM? This paper aims to figure out the perspectives from immigration and customs officers at border controls on the importance of integration of immigration and customs agencies in Indonesia. This study contributes to the proposed integration model of border agencies with a step-bystep process to the Indonesian government.

\section{THEORETICAL FRAMEWORK}

Complexities in the border clearance process at points of entry require strategies to protect and secure the border along with effective and efficient procedures. Two approaches may include in strategies are Integrated Border Management (IBM) and wholeof-government (WoG) initiatives. The significant variables in such approaches are threefold: collaboration, coordination, and cooperation. This section discusses the framework of Integrated Border Management and whole-of-government initiatives in border agencies in terms of law enforcement, economy, and community.

\section{Integrated Border Management}

The Integrated Border Management (IBM) framework has become an appropriate model to respond to the issues of border protection like transnational organized crime. In 2004, the European Commission published the guidelines for IBM in the Western Balkans ("European Commision: Guidelines for integrated border management in the Western Balkans," 2004) to define the concept of IBM, provide examples of IBM practices, strategies and action plans in border management. The guidelines comprise five parts: IBM pillars, main agencies of IBM, issues and concerns, IBM practices, development of strategies, and action plans. Three pillars of IBM are an intra-service agency, inter-agency, international cooperation, and collaboration, while IBM practices focus on the legal and institutional framework, procedures, human resources, information and data shares, and infrastructures. Duez (2016, pp.53-54) describes IBM in the EU as implemented in the Frontex EU border agencies, underpins border package, community approach, and new ICT roles. Border package refers to a series of border control strategies such as jointoperations, intelligence, information, and data analysis. In the use of technology, the 
Frontex rolls out the electronic border or smart border initiative; it is to strengthen border controls and create proactive policies of border control (Koslowski, 2003). IBM coexists with border control management (BCM), which consists of border risk management, border management assessment, and border management information system. Each state adopts various border technology and identification, such as biometric data of fingerprints and face recognition (Bossong \& Carrapico, 2016). This data is shared among border agencies to identify and detect any potential risks of international crime (Broeders \& Hampshire, 2013). IBM and BCM are intertwined, where states employ border security systems as the primary objectives to generate good impacts on economy and the community.

\section{Whole-of-Government Initiatives}

The integration of border agencies at airports, seaports, and land borders refers to a whole-of-government (WG) concept in public service reform. The term WG is coined after the join-up government concept, which response to the fragmented strategies of new public management, where it involves not only economic but also other approaches in social sciences (Bogdanor, 2005). In the public sector reform, Pollitt (2003) argues the joint-up-government approach merges coordination among government institutions in public services into one single process despite differences in policy. It works at all levels of government in policymaking and implementation, invites a participation of community, and public-private partnership (PPP). Meanwhile, at the street-level bureaucracy, Christensen and Lægreid (2007) mention WG initiatives blend public organizations in regions, local government institutions, with all stakeholders; it is a long-term development and sustainable program which takes time to adapt work cultures, structures, skills adoption, shared standards and joint system. In the study of WG approach (Olsen, 2013), it emphasizes the coordination among actors: politicians, public officials, policymakers from different departments, and stakeholders. To resolve a crisis in government institutions, the WG approach provides solutions for vertical and horizontal problems in public management, fragmented roles and functions, and competencies of human resources (Carayannopoulos, 2017, p.263).

Further, the WG extends to the e-government system to implement the use of ICT for seamless public service delivery. Jack (2018, p.234) claims the WG in the e-government system integrates service delivery processes, resources, information, and it reduces time and costs cutting bureaucracy towards effectiveness and efficiency in public service. It implies the WG initiatives in public sectors denote the IBM concept, which includes the framework of intra-agency and inter-agency collaboration, the use of technology in public service delivery to help the public servants. For example, issues and complexities in border protection in Australia triggered the Australian Government to integrate the customs 
agency (ACBPS) and immigration institution (DIBP) to become the Australian Border Force $(\mathrm{ABF})$ in 2015, demonstrating the intra-agency and inter-agency collaboration. It blends direction, policy, and agenda, which involves partnerships with other law enforcement agencies resulted in good impacts on law enforcement, economy, and community.

\section{RESEARCH METHOD}

This is quantitative survey research about perspectives on integration of border agencies through the IBM framework. To figure out the opinions, this paper applies the quantitative research method in which data is collected by an online survey (Google Form application). The online survey is conducted on 12-15 November 2019 because it is saving time and provide a real-time response. By a purposive random sampling, this survey is conducted to a sample of 177 respondents from 325 of the population from immigration and customs officers who are designated at five international airports, five seaports, and five border crossing stations with the greatest number of border-crossers. The five points of entry in Jakarta, Bali, Surabaya, Batam, and Makassar are the busiest airports and seaports with an increasing number of travelers and traders entering Indonesia and indicates complex border clearance processes. The data analysis is using the IBM SPPS statistical software because it is simple to use and provides precise and comprehensive statistical analysis. The Likert-type scale is selected to be the most appropriate survey for data collection and analysis of opinions, with 5\% margin of error and a 95\% confidence interval. The elements of integrated border management, referred to as a domestic integration among border authorities in one country, will be set in the form of eighteen questions based on the IBM pillars. To determine the sample size, this study implements the Slovin's formula with purposive random sampling. Respondent is categorized into four criteria: border officers, points of entry postings, at least one-year-work experience. 
Table 1. Study Variables and Items

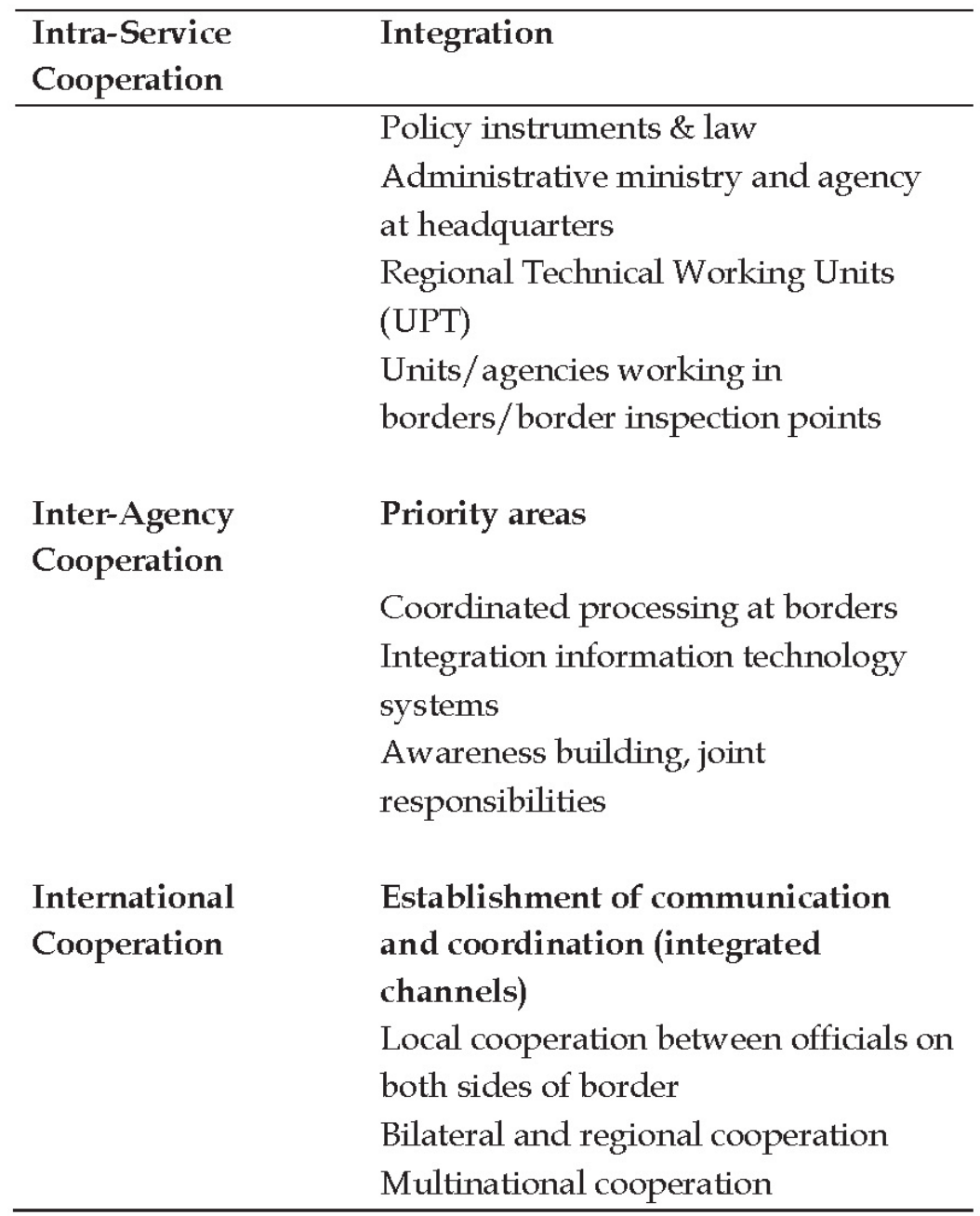

Source: (Guidelines for Integrated Border Management in the Western Balkans 2007)

\section{FINDINGS AND DISCUSSION Findings}

This section describes the result of the survey and shows the perspective of border officers towards an integration initiative between the DGI and DGCE to be one border agency in Indonesia. The data is collected from 144 respondents and classified into three categories: length of work, postings, and positions. Most respondents have been working at either DGI or DGCE Indonesia for two years and posting at international airports as immigration and customs officers/inspectors. The variety of length of work and positions may benefit this study to represent the perspectives of officers and to analyse the data, which becomes more accurate. 
Table 2. Data of Respondents

\begin{tabular}{lcc}
\hline \multicolumn{1}{c}{ Respondents } & Frequency & $\begin{array}{c}\text { Percentage } \\
\text { (\%) }\end{array}$ \\
\hline Length of Work & 78 & 54.2 \\
1-2 years & 40 & 27.8 \\
s3-4 years & 21 & 14.6 \\
5-10 years & 5 & 3.5 \\
Above 10 years & & \\
& & \\
Postings & 110 & 76.4 \\
International airport & 27 & 18.8 \\
International seaport & 7 & 4.9 \\
Border crossing station & & \\
& & \\
Positions & 75 & 52.1 \\
JFU (immigration and & & \\
customs officer/inspectors) & 17 & 11.8 \\
JA (managers) & 52 & 36.1 \\
JFT (immigration and & & \\
customs analyst) &
\end{tabular}

Source: Author's Survey Result 2020

After screening the survey data, missing values of six respondents have been replaced by using the means. The following Table describes no missing values with means of every indicator in three variables of 144 respondents. 
Table 3. Replacing Missing Values

\begin{tabular}{|c|c|c|c|c|c|c|c|}
\hline \multicolumn{8}{|c|}{ Univariate Statistics } \\
\hline & \multirow{3}{*}{$\mathrm{N}$} & \multicolumn{3}{|c|}{ Std. } & \multirow{2}{*}{\multicolumn{3}{|c|}{$\begin{array}{c}\text { No. of } \\
\text { Extremes }\end{array}$}} \\
\hline & & & Deviation & Missing & & & \\
\hline & & Mean & & Count & Percent & Low & High \\
\hline Intra_Serv1 & 144 & 4.20 & 1.138 & 0 & 0.0 & 15 & 0 \\
\hline Intra_Serv2 & 144 & 4.03 & 1.109 & 0 & 0.0 & 0 & 0 \\
\hline Intra_Serv3 & 144 & 3.94 & 1.283 & 0 & 0.0 & 0 & 0 \\
\hline Intra_Serv 4 & 144 & 4.08 & 1.229 & 0 & 0.0 & 20 & 0 \\
\hline Intra_Serv5 & 144 & 4.03 & 1.203 & 0 & 0.0 & 17 & 0 \\
\hline Intra_Serv6 & 144 & 4.07 & 1.138 & 0 & 0.0 & 17 & 0 \\
\hline Inter_Agen1 & 144 & 4.07 & 1.163 & 0 & 0.0 & 19 & 0 \\
\hline Inter_Agen2 & 144 & 4.19 & 1.206 & 0 & 0.0 & 19 & 0 \\
\hline Inter_Agen3 & 144 & 4.01 & 1.243 & 0 & 0.0 & 0 & 0 \\
\hline Inter_Agen4 & 144 & 4.13 & 1.178 & 0 & 0.0 & 18 & 0 \\
\hline Inter_Agen5 & 144 & 4.17 & 1.268 & 0 & 0.0 & 21 & 0 \\
\hline Inter_Agen6 & 144 & 4.01 & 1.220 & 0 & 0.0 & 0 & 0 \\
\hline Intl_Coop1 & 144 & 4.24 & 1.140 & 0 & 0.0 & 15 & 0 \\
\hline Intl_Coop2 & 144 & 4.26 & 1.056 & 0 & 0.0 & 12 & 0 \\
\hline Intl_Coop3 & 144 & 4.21 & 1.096 & 0 & 0.0 & 14 & 0 \\
\hline Intl_Coop4 & 144 & 4.11 & 1.116 & 0 & 0.0 & 15 & 0 \\
\hline Intl_Coop5 & 144 & 3.98 & 1.174 & 0 & 0.0 & 0 & 0 \\
\hline Intl_Coop6 & 144 & 4.17 & 1.177 & 0 & 0.0 & 16 & 0 \\
\hline Ideal_Intg & 144 & 1.36 & 0.482 & 0 & 0.0 & 0 & 0 \\
\hline
\end{tabular}

Source: Author's Data Screening 2020

However, thirty-eight respondents were excluded in the analysis because they are unengaged responses and outliers with below 0.2 of the standard deviation. The following Table is 106 selected respondents in a normal distribution where it shows a high standard deviation with more spread-out numbers, and most numbers are not close to the average. 
Table 4. Unengaged Responses and Outliers

\begin{tabular}{|c|c|c|c|c|c|c|c|}
\hline \multicolumn{8}{|c|}{ Descriptive Statistics } \\
\hline & $\mathrm{N}$ & Mean & Std. Deviation & Skewness & & Kurtosis & \\
\hline & Statistic & Statistic & Statistic & Statistic & Std. Error & Statistic & Std. Error \\
\hline Intra_Serv1 & 106 & 4.12 & 1.11 & -1.354 & 0.235 & 1.194 & 0.465 \\
\hline Intra_Serv2 & 106 & 3.88 & 1.066 & -0.807 & 0.235 & 0.006 & 0.465 \\
\hline Intra_Serv3 & 106 & 3.76 & 1.291 & -0.927 & 0.235 & -0.172 & 0.465 \\
\hline Intra_Serv4 & 106 & 3.94 & 1.241 & -1.202 & 0.235 & 0.474 & 0.465 \\
\hline Intra_Serv5 & 106 & 3.89 & 1.198 & -1.134 & 0.235 & 0.565 & 0.465 \\
\hline Intra_Serv6 & 106 & 3.93 & 1.115 & -1.044 & 0.235 & 0.463 & 0.465 \\
\hline Inter_Agen1 & 106 & 3.93 & 1.149 & -1.137 & 0.235 & 0.553 & 0.465 \\
\hline Inter_Agen2 & 106 & 4.09 & 1.223 & -1.329 & 0.235 & 0.717 & 0.465 \\
\hline Inter_Agen3 & 106 & 3.85 & 1.248 & -0.966 & 0.235 & -0.085 & 0.465 \\
\hline Inter_Agen4 & 106 & 4.02 & 1.179 & -1.281 & 0.235 & 0.826 & 0.465 \\
\hline Inter_Agen5 & 106 & 4.07 & 1.304 & -1.359 & 0.235 & 0.61 & 0.465 \\
\hline Inter_Agen6 & 106 & 3.85 & 1.217 & -0.964 & 0.235 & 0.074 & 0.465 \\
\hline Intl_Coop1 & 106 & 4.16 & 1.139 & -1.346 & 0.235 & 0.992 & 0.465 \\
\hline Intl_Coop2 & 106 & 4.19 & 1.025 & -1.472 & 0.235 & 1.94 & 0.465 \\
\hline Intl_Coop3 & 106 & 4.12 & 1.075 & -1.56 & 0.235 & 2.117 & 0.465 \\
\hline Intl_Coop4 & 106 & 3.99 & 1.091 & -1.416 & 0.235 & 1.679 & 0.465 \\
\hline Intl_Coop5 & 106 & 3.81 & 1.147 & -1.048 & 0.235 & 0.551 & 0.465 \\
\hline Intl_Coop6 & 106 & 4.07 & 1.181 & -1.402 & 0.235 & 1.21 & 0.465 \\
\hline Valid N (listwise) & 106 & & & & & & \\
\hline
\end{tabular}

Source: Author's Data Screening 2020 
Cronbach's alpha coefficient is above 0.9 , and it is reliable and has an excellent internal consistency that should exceed 0.7 (Hair, Ringle, \& Sarstedt, 2013, p. 7). It is important to measure the reliability of constructs and each indicator prior to data analysis.

Table 5. Reliability Test

\begin{tabular}{|c|c|}
\hline \multicolumn{2}{|c|}{ Reliability Statistics } \\
\hline Cronbach's & $\mathrm{N}$ of Items \\
\hline Alpha & \\
\hline 0.963 & 18 \\
\hline
\end{tabular}

Source: Author's Reliability Test 2020

The following Figure shows the perspectives from immigration and customs officers at border controls towards integration of immigration and customs agencies in Indonesia. The Figure illustrates that most border officers strongly agree, and more border officers agree with the border agencies in Indonesia with the concept of IBM. In contrast, less than $20 \%$ of respondents exposed their strong disagreement and disagreement with the IBM initiatives.

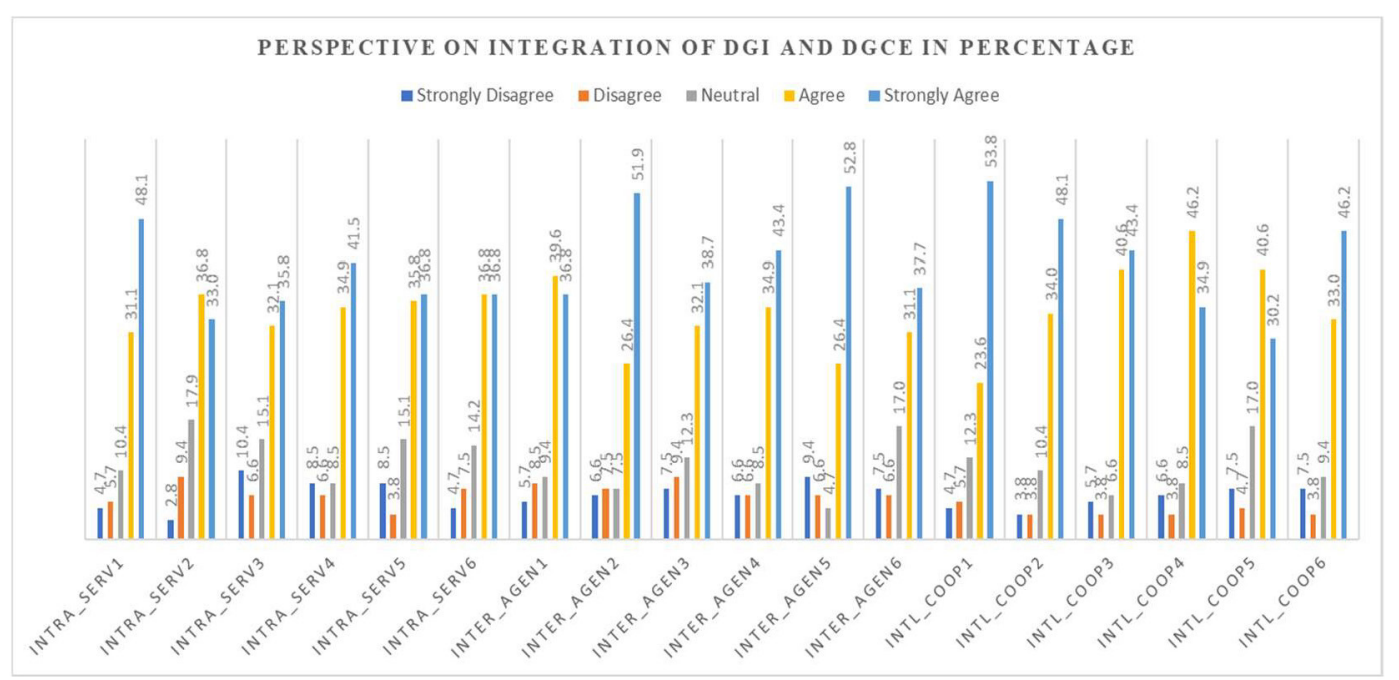

Figure 1. Perspectives on Integrated Border Management Initiatives in Indonesia Source: Author's Survey Result 2020 
The survey result implies that the integration of border agencies in Indonesia is the most important agenda which must apply the IBM strategy. The process of an integration shall consider three key variables in the IBM strategy. Intra-service cooperation is the first step to take with six indicators covering areas of policy instruments and laws, administration at all levels, regional technical work units (UPT), and units of inspection process at borders. The second step is to undertake the intra-agency cooperation that involves the coordination in border processing, integrated information systems and technology, and joint roles and responsibilities. International cooperation must be initiated in terms of the establishment of communication and coordination. This step shall build local cooperation from both sides of border agencies, bilateral and regional cooperation, and multinational cooperation.

Table 6. Ideal Integration of Border Agencies

\begin{tabular}{llcccc}
\hline \multicolumn{5}{c}{ Ideal Integration of Border Agencies } \\
\hline & & & Valid & Cumulative \\
& & Frequency & Percent & Percent & Percent \\
\hline \multirow{2}{*}{ Valid } & Integration of Institutions & 62 & 58.5 & 58.5 & 58.5 \\
& Joint Task Force & 44 & 41.5 & 41.5 & 100.0 \\
& Total & 106 & 100.0 & 100.0 & \\
\hline
\end{tabular}

\section{Source: Author's Survey Result 2020}

In terms of integration of border agencies, $58.5 \%$ of respondents agree that the integration of institutions is more appropriate than only a joint-task force, with $44 \%$ of respondents. It means the ideal integration of border agencies in Indonesia should adopt the integration of institutions at all levels and actors rather than a joint task force. It infers that border agencies in Indonesia are merged into one body, which is not building temporary cooperation like a border task force.

\section{Analysis}

Border agencies in Indonesia have essential responsibilities in expediting border inspections, border security, and border law enforcement. They protect borders at airports, seaports, and border crossing stations across Indonesia. In international airports and seaports in Indonesia, border inspection agencies or called CIQ consist of quarantine agency under the Ministry of Agriculture and Ministry of Health, immigration under the Directorate General of Immigration, Ministry of Law and Human Rights, and customs under the Directorate General of Customs and Excise, Ministry of Finance. In international 
border crossing stations at land borders, the CIQ works together with the Indonesian Military Forces (TNI), Indonesian National Police (Polri), and National Cross-Border Management Agency (BNPP). This environment tends to cause poor coordination, fragmented policy, blurring authority, or dispute in implementing laws. The IBM concept might address these concerns, in the beginning, by integrating the immigration and customs agency in Indonesia.

Towards an integration initiative between the DGI and the DGCE referring to the IBM concept, both institutions, at the first stage, must undertake intra-service cooperation. The integration and reconstruction of border regulations (or omnibus bill) focus on integrated and comprehensive policy instruments that manage the integration of institutions. This step begins with the reorganizing administrative ministry and agency at headquarters by restructuring the public managers, vision, mission, roles, responsibilities, functions. At the regional levels, each border work unit (UPT) of DGI and DGCE is integrated, including divisions or sections in customs and immigration offices dealing with border inspections. In so doing, the WG approach underpins the coordination among politicians, public officials, policymakers from different departments, and stakeholders (Olsen, 2013). It assumed that the integration of these two institutions would take a longterm project through a long and winding bureaucratic process (Christensen \& Lægreid, 2007).

In addition to restructuring organizations, this policy must cover a border pre-clearance process, procedures, and standards of entry and exit at borders by conducting a seamless border control through an immigration and customs inspection. Under the bilateral agreement, border pre-clearance at airports is an immigration clearance and customs inspections before passengers board the flights, not when they arrive at destination country (Hiller, 2010, p. 28). Also, the provisions regulate entry requirements for passengers, border crossers, crew members, transports, and denied entry or charges/fee liability. Besides, policy on revenue collection, such as tax and non-tax from border control activities, is integrated in terms of scheme and allocation. DGI and DGCE share risk management, border management, and quality control at borders because they will have mutual objectives and targets like transnational organized crime.

In the practical step, secondly, interagency cooperation shall be applied along with three priority areas: coordinated processing at borders, an integration of border technology, and awareness building or joint responsibilities. Coordinated border clearance process can be performed at all points of entry and exit, including the decision-making process subject to an individual, travel documents, and belongings, goods, or items they bring. This clearance process is equipped with an integrated information system and management consisting of Advance Passenger Information (API), Passenger Name Record (PNR), passenger moving system (PMS), movement alert list (ECS), I-24/7 Interpol system 
(Arifin, Nurkumalawati, \& Briando, 2019), and Indonesian National Single Window or INSW (Das, 2017). The integrated information system among border agencies is relevant to the WG approach (Jack, 2018, p.234) to apply an e-government concept towards a seamless border control process.

In relation to human resources development, all border officers from different units must attend the intensive joint training programs about procedures and standards, immigration law, customs law, border law enforcement, and international conventions. Border officers will share roles and functions in clearance processes where they must understand the entry requirements of the person, travel documents, goods, or items. In this sense, decision making is a collective collegial procedure by identifying what categories and indicators a person must comply with. Joint patrol is conducted by immigration officers and customs officers along the borderline at border crossing stations and sea borders. For future border officers, new recruits are selected based on an integrated framework of standardized job competencies, qualifications, and capabilities. Although they apply the similar concept of KSAO (knowledge, skills, abilities, and other characteristics), border security officer competencies are unique (Chia, Heng, Goh, \& Ang, 2019).

In the third step, IBM is initiating international cooperation through an establishment of communication and coordination or integrated channels. It is to build a strategic partnership, coordination, and communication with border agencies of neighboring countries such as ICA Singapore, ABF Australia, Immigration Department of Malaysia, Airline Liaison Officer, etc. Bilateral and regional cooperation with foreign representatives, ASEAN, or APEC, is important to collaborate to build a stronger relationship in diplomacy. For combating transnational organized crime, an integrated framework of cooperation must be constructed with international law enforcement agencies such as Interpol, FBI, Australian Federal Police, CIA, etc. The number of international crimes is increasing, and it is essential to build multilateral coordination with UNODC, UNHCR, IOM (International Organization of Migration), WCO (World Customs Organization) and other organizations under the United Nations (UN). All intergovernmental organizations are responsible for international migration governance, where a host country must take part in the coordination and arrangement of people (Kunz, Lavenex, \& Panizzon, 2011, p. 28). Border agencies must have an intensive communication and coordination with international ports administrator or authority and international border crossing stations like BNPP to implement a border pre-clearance process. 


\section{CONCLUSION}

IBM concept and whole-of-government approach are to respond to the challenges in the border protection between two Indonesian border agencies that indicate weaknesses in coordination, fragmented policy instruments, and dispute in implementing laws. This study result demonstrates that it is very important to apply the integration of immigration and customs agencies in Indonesia. The integration initiative is adopting the IBM framework with three pillars and a whole-of-government concept by a method of working to create incremental changes. Of these, initiating the integration of institutions between the Directorate General of Immigration and Directorate General of Customs and Excise is more ideal border agencies rather than a joint-task force. In the future, this border agency may be an independent institution such as ICA Singapore (Immigration and Checkpoints Authority), ABF (Australian Border Force), or Frontex (European Border Agency), and the agency has a direct responsibility to the president.

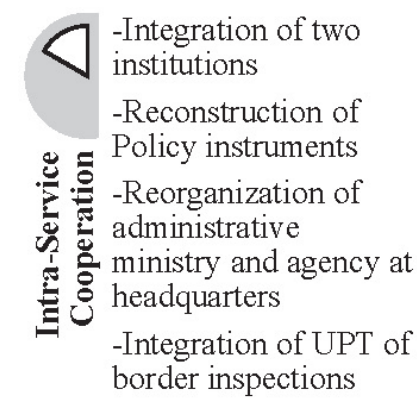

-Coordinated border clearance process -Integration of information sytem:

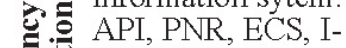
$24 / 7$, INSW $\sum_{1} \frac{5}{\circ}$-Integration of 递 training programs

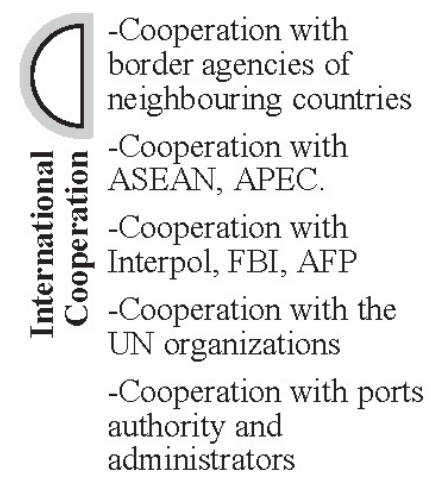

Figure 2. A Step-by-Step Process of Integration between DGCE and DGI with IBM Concept

Source: Author's Data Analysis 2020

This paper may provide solutions for some issues of border protection in Indonesia by implementing the IBM framework with three pillars and whole-of-government (WoG) initiatives. The IBM initiatives and WG concept subscribe to collaboration, coordination, and cooperation. Further study should consider a more comprehensive study on integration of Customs, Immigration, and Quarantine (CIQ) about roles, functions, responsibilities, and guidelines of the integrated border management in Indonesia. 


\section{REFERENCES}

Arifin, R., Nurkumalawati, I., \& Briando, B. (2019). The Theoretical Perspectives of Immigration Controls: Immigration Clearance Process, Selective Policy and Security Apporach at Airports in Indonesia In Second International Conference on Multidisciplinary Academic Research (pp. 251-260). Sydney: Asia Pacific Institute of Advanced Research

Bogdanor, V. (2005). Joined-up government (Vol. 5): Oxford University Press.

Bossong, R., \& Carrapico, H. (2016). EU Borders and Shifting Internal Security Technology,

Externalization and Accountability (1st ed. 2016. ed.): Cham : Springer International Publishing : Imprint: Springer.

BPS. (2018). Jumlah kunjungan wisman ke Indonesia Agustus 2018 Retrieved from https:/ /www.bps.go.id/

Broeders, D., \& Hampshire, J. (2013). Dreaming of Seamless Borders: ICTs and the PreEmptive Governance of Mobility in Europe. Journal of Ethnic and Migration Studies, 39(8), 1201-1218. doi:10.1080/1369183X.2013.787512

Carayannopoulos, G. (2017). Whole of Government: the Solution to Managing Crises? Australian Journal of Public Administration, 76(2), 251-265.

Chia, Y., Heng, W., Goh, L., \& Ang, C. (2019). Job Competencies of Border Security Officers in Singapore. Journal of Police and Criminal Psychology, 1-13.

Christensen, T., \& Lægreid, P. (2007). The whole of government approach to public sector reform. Public Administration Review, 67(6), 1059-1066.

Das, S. B. (2017). ASEAN single window: Advancing trade facilitation for regional integration.

Duez, D. (2016). A Community of Borders, Borders of Community: The EU's Integrated Border Management Strategy. In E. Vallet (Ed.), Borders, fences and walls: State of insecurity? (pp. 51-66). London: Routledge.

European Commision: Guidelines for integrated border management in the Western Balkans. (2004). In. Europe: European Commission.

Guidelines for Integrated Border Management in the Western Balkans (2007). Europe Retrieved from https://www.legislationline.org/download/id/3647/file/ BC\%20Guidelines\%2Offor\%2OIntegrated\%20Border\%20Management\%2Oin\%20the\%20Westem\%20Balkans\%202007.pdf

Hair, J. F., Ringle, C. M., \& Sarstedt, M. (2013). Partial least squares structural equation modeling: Rigorous applications, better results and higher acceptance. Long range planning, 46(1-2), 1-12.

Hiller, H. H. (2010). Airports as borderlands: American preclearance and transitional spaces in Canada. Journal of Borderlands Studies, 25(3-4), 19-30.

Jack, J. (2018). E-government in Vanuatu: a whole-of-government approach. Asia Pacific Journal of Public Administration, 40(4), 228-234.

Keputusan Menteri Hukum dan HAM No.M.HH-02.GR.02.02 Tahun 2020 tentang Tempat Pemeriksaan Imigrasi. 
Koslowski, R. (2003). Information technology and integrated border management. Paper presented at the Proceedings of the Workshop on Managing International and InterAgency Cooperation at the Border.

Kunz, R., Lavenex, S., \& Panizzon, M. (2011). Multilayered migration governance: The promise of partnership (Vol. 89): Taylor \& Francis.

Olsen, G. R. (2013). Whole-of-government approaches to fragile states in Africa. Third World Quarterly, 34(10), 1828-1842.

Pollitt, C. (2003). Joined-up government: a survey. Political studies review, 1(1), 34-49.

Undang-Undang No.6 Tahun 2011 tentang Keimigrasian Indonesia.

Undang-Undang Nomor 17 Tahun 2006 tentang Kepabeanan. 


\section{APPENDIX}

\section{Questionnaire}

\begin{tabular}{|c|c|c|}
\hline No & Variables & Questions \\
\hline 1 & $\begin{array}{l}\text { Intra-Service } \\
\text { Cooperation }\end{array}$ & $\begin{array}{l}\text { Integrasi dan rekonstruksi peraturan-peraturan perbatasan } \\
\text { (omnibus law) seperti kebijakan, ketentuan/ SOP } \\
\text { pemeriksaan kru, penumpang, pelintas batas, alat angkut; } \\
\text { persyaratan masuk, penolakan masuk, denda/ biaya beban, } \\
\text { dsb. }\end{array}$ \\
\hline 2 & & $\begin{array}{l}\text { Integrasi kebijakan anggaran termasuk pemasukan (Pajak } \\
\text { dan PNBP/ revenue collection) antara DJBC dan Ditjenim } \\
\text { dalam pelaksanaan tugas dan fungsi. }\end{array}$ \\
\hline 3 & & $\begin{array}{l}\text { Integrasi Direktorat Jenderal Bea dan Cukai (DJBC) dengan } \\
\text { Direktorat Jenderal Imigrasi (Ditjenim) secara struktur (Orta), } \\
\text { visi-misi, fungsi, peran, tugas dalam satu Kementerian (di } \\
\text { Kementerian Keuangan, atau di Kementerian Hukum dan } \\
\text { HAM atau menjadi Kementerian Baru). }\end{array}$ \\
\hline 4 & & $\begin{array}{l}\text { Integrasi Unit Pelayanan Teknis (UPT) seperti Kantor Bea dan } \\
\text { Cukai dengan Kantor Imigrasi di setiap daerah yang } \\
\text { beroperasi di pintu-pintu masuk (Bandara, Pelabuhan, } \\
\text { PLBN). }\end{array}$ \\
\hline 5 & & $\begin{array}{l}\text { Integrasi Bidang atau Unit di bawah Kantor Bea Cukai dan } \\
\text { Kantor Imigrasi di seluruh pintu-pintu masuk (Bandara, } \\
\text { Pelabuhan, PLBN). }\end{array}$ \\
\hline 6 & & $\begin{array}{l}\text { Integrasi manajemen risiko (risk management), manajemen } \\
\text { perbatasan (border management), uji kualitas (quality } \\
\text { control) antara DJBC dan Ditjenim. }\end{array}$ \\
\hline 7 & $\begin{array}{l}\text { Inter-Agency } \\
\text { Cooperation }\end{array}$ & $\begin{array}{l}\text { Integrasi proses pemeriksaan Imigrasi dan Bea Cukai di } \\
\text { seluruh pintu-pintu masuk (Bandara, Pelabuhan, PLBN) } \\
\text { termasuk pengambilan keputusan. }\end{array}$ \\
\hline 8 & & $\begin{array}{l}\text { Integrasi sistem informasi dan teknologi dalam proses } \\
\text { pemeriksaan Imigrasi dan Bea Cukai di seluruh pintu-pintu } \\
\text { masuk (Bandara, Pelabuhan, PLBN). }\end{array}$ \\
\hline 9 & & $\begin{array}{l}\text { Integrasi tugas dan fungsi, kewajiban/ tanggung jawab } \\
\text { dalam proses pemeriksaan Imigrasi dan Bea Cukai di seluruh } \\
\text { pintu-pintu masuk (Bandara, Pelabuhan, PLBN). }\end{array}$ \\
\hline 10 & & $\begin{array}{l}\text { Integrasi patroli keamanan perbatasan bersama antara } \\
\text { Imigrasi dan Bea Cukai di seluruh pintu-pintu masuk } \\
\text { (Bandara, Pelabuhan, PLBN). }\end{array}$ \\
\hline 11 & & $\begin{array}{l}\text { Integrasi pelatihan-pelatihan keamanan perbatasan, } \\
\text { keimigrasian, bea cukai, penegakan hukum perbatasan } \\
\text { (peningkatan SDM) }\end{array}$ \\
\hline 12 & & $\begin{array}{l}\text { Integrasi proses rekrutmen pegawai baru melalui satu } \\
\text { sumber: standar, kualifikasi, kompetensi, kapabilitas. }\end{array}$ \\
\hline
\end{tabular}




\begin{tabular}{ll}
\hline 13 International & Membangung integrasi kerja sama, koordinasi dan \\
Cooperation & komunikasi dengan pihak perbatasan (CIQ) negara tetangga \\
& (berbatasan langsung) seperti dengan ALO, ICA, ABF, \\
& Imigresen Malaysia, dsb. \\
& Membangung integrasi kerja sama, koordinasi dan \\
& komunikasi bilateral dan regional seperti dengan Kedutaan \\
& Besar, IOM, WCO, KIS, ICAO, IMO, ASEAN, MEA, operator \\
& alat angkut. \\
& Membangung integrasi kerja sama, koordinasi dan \\
& komunikasi antarlembaga penegak hukum dalam negeri \\
& seperti dengan TNI, Polri, Bakamla, BNPP, KKP, BNPT, BIN \\
& dsb. \\
& Membangung integrasi kerja sama, koordinasi dan \\
& komunikasi antarlembaga penegak hukum internasional \\
& seperti dengan AFP, Interpol, FBI, dsb. \\
& Membangung integrasi kerja sama, koordinasi dan \\
& komunikasi multilateral seperti dengan PBB (United \\
& Nations), OKI, APEC, OPEC, World Bank, WTO dsb. \\
& Membangung integrasi kerja sama, koordinasi dan \\
& komunikasi dengan pihak bandara dan pelabuhan \\
& internasional di luar negeri dalam hal pemeriksaan imigrasi \\
& dan bea cukai pra-kedatangan (border pre-clearance). \\
& Menurut Anda, bentuk integrasi institusi perbatasan yang \\
& ideal antara DJBC dan Ditjenim di perbatasan negara \\
& (Bandara, Pelabuhan, PLBN): \\
& A. Tim Satgas Gabungan (Joint Task-Force) \\
& B. Integrasi Institusi (seperti ABF, ICA, Fontex, CBP, ICE) \\
\hline &
\end{tabular}

